\begin{tabular}{l|l}
\hline Potaice & e-ISSN: 2655-9404 \\
Vol. 2 No. 1, Februari 2019 & DOI: 10.20473/ntr.v2i1.13069 \\
\hline
\end{tabular}

Article history: Submitted 15 December 2018 ; Accepted 8 January 2019; Available online 1 February 2019.

\title{
Status of Waqf Properties As Debt's Collateral
}

\author{
Intan Avi Savila, Made Ayu Trisnawati and Notaricia Sartika \\ intanavi@gmail.com, ayu.trisna9654@gmail.com, notaricia@gmail.com \\ Universitas Airlangga
}

\begin{abstract}
In Law Number. 20 of 2011 on Strata Title, there is a provision for strata title that stand on waqf land. A person who has a flat on the waqf land will be given a Strata Title Ownership Certificate (SKBG) as proof of his rights in writing. This SKBG can be used as a fiduciary guarantee in accordance with Law Number 42 of 1999 on Fiduciary Guarantee. Lack of understanding about the representative, raises problems regarding waqf such as making waqf land as collateral for debt. In Article 40 letter (a) Law No. 41 of 2004 on Waqf there is a prohibition on waqf property as collateral. By making waqf land as collateral for debt will have consequences for the guarantee agreement. This happened because of the lack of awareness of the management of waqf property from nadzir, the community and the bank as a creditor to the implementation of changes in the status of waqf property. So that the consequences of the SKBG on waqf land or those that are used as fiduciary collateral or waqf land certificates that are guaranteed as collateral rights, debt receivables are not necessarily null and void, but repayment of debts must still be fulfilled by the debtor with the changed guarantee guarantee with Article $1131 \mathrm{BW}$. This is because the execution of SKBH on waqf land will be difficult, considering that the SKBG only binds the building. Efforts are needed to minimize problems about waqf by conducting socialization to nadzir, heirs, banks as creditors to the wider community regarding representatives, especially changes in the status of waqf property so that there are no more problems in the implementation and management of waqf property in the future.
\end{abstract}

Keywords: Waqf properties; Collateral; Debt.

\begin{abstract}
Abstrak
Kurangnya pemahaman tentang perwakafan tanah, menimbulkan permasalahan mengenai wakaf seperti menjadikan tanah wakaf sebagai jaminan utang piutang. Didalam Pasal 40 huruf (a) Undang-Undang No. 41 Tahun 2004 tentang Wakafterdapat larangan harta benda wakaf dijadikan sebagai jaminan. Pelaksanaan perubahan status harta benda wakaf yang tidak sesuai dengan UU No. 41 Tahun 2004 tentang Wakaf, salah satunya dengan menajdikan tanah wakaf sebagai jaminan utang akan menimbulkan konsekuensi terhadap perjanjian jaminan tersebut. Pada kenyataan dimasyarakat masih terdapat pelanggaran terhadap ketentuan Pasal 40 huruf (a) Undang-Undang Nomor 41 Tahun 2004 tentang Wakaf. Hal ini terjadi karena minimnya kesadaran akan pengelolaan harta benda wakaf dari nadzir, ahli waris serta pihak bank sebagai kreditur terhadap pelaksanaan perubahan status harta benda wakaf. Sehingga konsekuensi terhadap perubahan status harta benda wakaf yang melanggar pasal 40 huruf (a) UU No. 41 Tahun 2004 tentang Wakaf tidak serta merta batal demi hukum, namun pelunasan utang-piutang tetap harus dipenuhi oleh debitur sesuai dengan pasal 1131 BW. Dibutuhkan adanya upaya untuk meminimalisir permasalahan tentang wakaf dengan dilakukannya sosialisasi kepada nadzir, ahli waris, bank sebagai kreditur hingga masyarakat luas mengenai perwakafan, khususnya perubahan status harta benda wakaf supaya tidak ada lagi permasalahan dalam pelaksanaan dan pengelolaan harta benda wakaf di kemudian hari. Kata Kunci: Benda Wakaf; Jaminan; Utang Piutang.
\end{abstract}




\section{Introduction}

Waqf is a form of worship, which has material nature that have been known for so long. This institution has been existed since communal life formed. Every group of people always providing public service required concurrently by people. Worship place, road, water sources, and other public facilities. ${ }^{1}$ Word of waqf that have been adopted into Indonesian actually derived from Arabian language verb that etymologically means to hold. ${ }^{2}$

Refer to Syafi'i's school of thought, waqf can be translated to hold property that benefit can be taken with the fullness of the goods and the property ownership will transferred from waqif (waqif is person whose put their own properties into waqf), and utilized on something allowed. Definition that given above by Syafi'i's school of thought shown the firmness towards ownership status of waqf properties. When the waqf declared legitimate; then, the ownership over waqf properties change from the originated owner to Allah SWT, through the understanding that the properties included as waqf will be owned by ummah' or people and won't be own by the person whose conducted waqf. Thus, the relation between the person whose conduct waqf and their properties will be separated; at once, there will be new relation arises between those properties and Allah SWT. Therefore, as the feedback of the good deeds conducted by the person, they will be honored with pahala by Allah SWT. It is expected that the separation of relation between the person whose have been conducted waqf and their properties will make the person perform waqf sincerly. ${ }^{3}$

Based on customary law's perspective, the person whose conducts waqf must have rights and full authority over the object that included as waqf, the object must be clearly appointed and shall not used on purpose that not allowed in Islam, the Halal objective must be defined clearly, even then the objective shown unexpectedly, is not obvious itself, the objective must be fixed, the person whose given authorization on waqf properties must be appointed as clear as possible and

\footnotetext{
Farid Wajdi dan Suhrawardi K, Hukum Wakaf Tunai (Citra Aditya Bakti 2016).[1].

Suhrawardi K, Wakaf Dan Pemberdayaan Umat (Sinar Grafika 2010).[3].

3 ibid. [5].
} 
in what degree that person agreed to received the authorization that have been given to them. Waqif could implement the management over the waqf property through appointment of person in charge over the waqf property or nadzir, if there isn't any (in Java, the person whose obliged to manage the waqf is mosque's head caretaker). If the creation of waqf have been completed (creation of waqf deed); therefore, legal standing of the property will be ruled under customary law (with it's religious characteristic), every matters that must be done to achive the objective are the person in charge over the waqf, including submitting case to the court. ${ }^{4}$

Prior the Law Number 41 Year 2004 on Waqf, the current law that regulates matters on land waqf with ownership title could open the opportunity of unexpected result caused by unavailability of comprehensive datas on land waqf. Sometimes there is deviation of essence and purpose of waqf itself, especially caused by requirement that not oblige to register the waqf properties ; thus, many of waqf properties that became untraceable, and in some condition the waqf properties are recognized unilaterally by the nadzir. Those situations create anxiety among people, especially persons whose embrace Islam and lead to antipathy. On the other hand, many issues on land waqf are caused by obscurity of owner and nadzir.

Basically, nadzir is the party who's received waqf property from wakif to be managed and developed in accordance to the purpose and objective enacted by wakif that includes individual, organization or legal entity. Organization or legal entity are managed by person whose ensconce under association. As a person, there is three interpersonal needs, including inclusion, control, and affection needs. ${ }^{5}$

Land rights are immovable objects that can be represented so that the land becomes waqf land. In Strata Title Law (Undang-Undang Rumah Susun) there are new innovations that provide opportunities for waqf land to be used for the construction of flats with lease agreements or cooperation in the utilization of waqf assets that remain

\footnotetext{
4 Rachmadi Usman, Hukum Perwakafan Di Indonesia (Sinar Grafika 2013).[75-76].

5 Soerjono Soekanto, Hukum Adat Indonesia (Rajagrafindo Persada 2012).[64].
} 
in the corridor of utilizing waqf property for the benefit of the people ${ }^{6}$ Construction of Strata Title on waqf land through leasing endowments creates a legal lease event between nadzir as a management for caretaker and third parties who will rent waqf land for the construction of strata title. After the construction is completed, the apartment building will be traded to the community to become their residence with proof of ownership of the SKBG (strata title ownership certificate).

Accompanied with variation of needs needed by humans, there may arise human's will to fulfill those desire without reconsider the prolonged risk. Moreover, in the present many people whose become consumptive; thus, people tends to do anything in order to fulfill those desire (i.e. tertiary needs). There will also possibilities that nadzir or owner of SKBG may also conduct these unlawful things, and deviates from the responsibility authorized to them and utilized waqf property for their own behalf, i.e. include the waqf properties as debt's collateral. There are also great possibilities that waqf properties' heir retake the property that have been included as object of waqf. Even though, through waqf, the land that have been included as waqf property already had their fix objectives given by the wakif, and this objective can't be altered. Through waqf, the land has been taken out from the trade traffic (in de dode hand gebracht), which means it couldn't become object of legal action in form of transfer of right, can't be burdened with other rights and unavailable as object of debt's collateral that may altered the allotment of waqf property itself. ${ }^{7}$

\section{Discussion}

Transformation of waqf land is a form of legal action. As stated on Article 40 Law Number 41 Year 2004 on Waqf, waqf land prohibited to be included as collateral, confiscated, bequested, sold, inherited, traded or any other forms of transfer of right. This article intended for protecting waqf assets from any missused. However, transformation of waqf land status could be excepted, if waqf land will be

${ }^{6}$ Novita Try Jayanti, 'Penggunaan Tanah Wakaf Untuk Pembangunan Rumah Susun' (Universitas Airlangga 2018).[38].

${ }^{7}$ Soerjono Soekanto (n 5).Op.Cit.[74]. 
used for public interest correspond to General Spatial Plan or Rencana Umum Tata Ruang (RUTR) based on applicable laws that don't oppose Syariah.

As living creature with natural condition that always changing in this planet, human trusted by Allah SWT to manage and utilize this nature. However, not all human has good morals as in the waqf land utilization had shown that nadzir, who should be trustworthy sometimes conducts unlawful act like utilize waqf land for their own behalf, isn't responsible for their own conduct, and ignore the purpose of the waqf stated on ikrar wakaf or waqf deed. This situation resulting complains and anxiety within the society. If this situation ignored continuously, not only it will reduce the benefits of waqf, but it could reduce the Muslims awareness and motivation to do waqf; therefore, it will reduce the function of waqf on development of nation and country.

Basically, the purpose and utilization of ownership right title's land that have been included as waqf property can't be change besides that have been stated on waqf deed. However, through certain reasons after given written permission from minister of religion, the purpose of land waqf could be utilized beside that have been stated on the waqf deed. These limitations have certain purpose to avoid misuse of waqf property. Transformation of waqf land status and its purpose must be reported by nadzir to regency/city head of agrarian office in order to receive further settlement in accordance to Law Number 41 Year 2004 on Waqf. ${ }^{8}$

Economic development of waqf property accounted will be better if the Islamic development expert research result applied on suitable situation and condition. Several policies that have been applied by Rasulullah and Sahabat shall turned into principle and example in order to improve economic value of waqf property. The intended policies are related to utilization of waqf, merger of waqf properties, substitution of waqf management etc. while not opposing the Islamic law. ${ }^{9}$ 2005).[98].

${ }^{8}$ Husein Syahatah, Perlindungan Aset Publik Dalam Perspektif Hukum Islam (Bumi Aksara

9 Suhrawardi K (n 2).Op.Cit.[89]. 
Waqf practiced on the society haven't been execute efficiently and orderly yet. Therefore, on many cases the waqf property weren't managed properly, abandoned or transferred to third party's ownership unlawfully. These conditions, happened not only because of negligence or incapability of nadzir to manages and develops waqf property, but also because of society ignorance and incomprehension towards waqf property that should be protected for the sake of public welfare correspond to waqf properties' purpose, function, and allotment.

\section{Waqf Deed as Collateral on Loan Agreement}

On the loan agreement, bank will not grant the loan if without considering the collateral given by debtor. Therefore, bank gives requirement for the debtor to gives collateral for the loan secureness and observe the feasibililty of a business. Following the national development that emphasizing on economy, which requiring large sum of funds; thus, the existence of collateral institution that capable to grant protection and legal certainty for parties that could improve people participation on the development based on Pancasila and laws. ${ }^{10}$

Land and bulding are kind of the collaterals favoured by financial institution to grant loan facility. The reasons are the liquidity, constant price improvement, ownership deed, difficult to embezzled and can be burdened with Hak Tanggungan or Fidusia right that grant special right for the creditor.

Law Number 4 Year 1996 on collateral institution called Hak Tanggungan, which being used to includes loan object in form of land or object related to the land. Through the enactment of Law Number 4 Year 1996, Hipotek that regulated on Burgerlijk Wetboek or Indonesian Civil Code and credit verband that used to utilize in mortgaging land as loan collateral are not used anymore for those specific purposes. Since the enactment of Law Number 4 Year 1996 on $9^{\text {th }}$ April 1996 all mortgage of collateral in form of land will be fully conducted through Hak Tanggungan. ${ }^{11}$

\footnotetext{
${ }^{10}$ Adrian Sutedi, Hukum Hak Tanggungan (Sinar Grafika 2012).[16].

11 Bahsan, Hukum Jaminan Dan Jaminan Kredit (Raja Grafindo Persada 2010).[22].
} 
Hak tanggungan that regulated on Law Number 4 Year 1996 wasn't completely originate from inexistent. Hak tanggungan constructed through take over or refer to core principles and provisions of Hipotek regulated on Burgerlijk Wetboek. Hak tanggungan will be given if only preceded by main agreement in form of loan agreement that will bring forth legal relationship of loan that guaranteed with hak tanggungan, correspond with accesoir characteristic from hak tanggungan collateral agreement. ${ }^{12}$

Land rights that can become the object of hak tanggungan are ownership right title's land, land of business use right, and land of building use right. Besides land right mentioned before, rights to use on state land in accordance with the applicable law must be registered first, which based on its characteristic it right can be transferred to other party and can be imposed with hak tanggungan. Hak tanggungan also can be imposed on the land right including building, plant, and attainments that will or already exist that attached to the land, and which is the property of the holder of the right to land that is stated in the deed of imposing hak tanggungan over the related rights. If the particular building, plant and attainments don't own by the right holder, impose of hak tanggungan only capable to be done through signing on the deed of imposing hak tanggungan by the owner or person who became representative for it in form of authentic deed.

It can be taken into conclusion, the building that capable to be imposed with hak tanggungan on the particular land right includes: building that stood over or under the particular land, i.e. basement related to particular land right. As for the authentic deeds in question is power of attorney deed to impose hak tanggungan together with particular land.

Related to both requirements stated before, ownership right that already included as waqf property can't be imposed with hak tanggungan, because in accordance to the principle of waqf, ownership right of the waqf property have been perpetuated into religious property. In accordance with that principle, land

\footnotetext{
${ }^{12}$ Rachmadi Usman, Hukum Jaminan Keperdataan (Sinar Grafika 2009).[411].
} 
right that utilized for religious purposes also unavailable to be imposed with hak tanggungan.

Similar to hak tanggungan, jaminan fidusia are material rights that have precedence over other creditors to take repayment of their receivables from the execution of objects that become jaminan fidusia, if the Fiduciary or Debtor defaults or breaches of contract. ${ }^{13}$

Based on the waqf property characteristic; therefore, land that already included as waqf by the wakif will be given certain purposes permanently and it can't be change except for public interest. Through waqf, the land has been taken out from the trade traffic (in de dode hand gebracht), which means it couldn't become object of legal action in form of transfer of right, can't be burdened with other rights and unavailable as object of debt's collateral. ${ }^{14}$

In case of waqf land still utilized as debt's collateral object; therefore, it is won't be in accordance with the content of the waqf deed that have been agreed between wakif and nadzir. The general purpose of waqf itself is to perpetuate benefit in accordance with purpose of waqf that have been agreed and stated in the waqf deed, which is to achieve public welfare, and used as facility for benefit of religious society.

\section{Consequences of Waqf Deed Inclusion in Collateral Agreement}

Legality of agreement regulated under Article $1320 \mathrm{BW}$; this article regarded as core article in Indonesian Civil Code because under this article stipulated regarding the requirement of contract's legality. Those requirements, either related to party whose construct the contract and commonly called as subjective requirement or related to the substance of the contract itself and commonly called as objective requirement.

Agreement that meant by this Article is adjustment of parties will, which is meeting between offer and acceptance. This agreement can be achieved through several manners, either written or written. It called as unwritten manner because it

${ }^{13}$ Fatma Paparang, 'Implementasi Jaminan Fidusia Dalam Pemberian Kredit Di Indonesia' (2014) 1 LPPM Bidang EkoSosBudKum.[65].

${ }^{14}$ Rachmadi Usman (n 4).Op.Cit.[74]. 
even can be achieved through communication using symbol.

Meanwhile, capacity is the legal competence of contract subject to perform legal action, which is to agreed into contract. This capacity measured with the age of the legal subject is over 21 years old or have been married. Legal competence to perform legal action also can be seen from the authority and position of the legal subject.

Although, based on the marriage law (Undang-Undan Perkawinan) the standard of legal capacity measured with the age of 18 or have been married, not all person that fulfil those standards deemed as capable to perform legal action. This is because of the possibilities that the person fulfilled the standard might be under guardianship, which meant that they are still deemed incapable to perform legal action.

In regard to certain things is the third requirement of contract legality, which explained as the obligation for parties to have certain object in the contract, that must be defined clearly and shouldn't be misled.

The fourth requirement is causes allowed or kausa yang diperbolehkan his is related to the substance of the contract. In this term halal word isn't mean to be opposed with haram as what have been taught in Islam. However, what actually meant is that the substance of the contract mustn't oppose the law, moral, and public order. ${ }^{15}$

Debt collateral agreement that include waqf deed as its collateral, clearly regarded as unlawful conduct. Meaning, in this contract, the waqf land as the collateral object is not allowed to be included as object of debt collateral agreement by Laws, either Law Number 41 Year 2004 on Waqf or Law Number 4 Year 1996 on Hak Tanggungan stipulated relates to waqf property upkeep as property used for people welfare and social interest that still within sharia corridor. Waqf land can be included as public assets, which is property owned by all people and all people can be benefited from it without any unilateral monopoly or exploitation for individual interest. On the other hand, public asset can be enjoyed by all people or all member of certain community who owns the waqf property, without any constriction of prerogative right on certain individual. Therefore, it can be concluded that collateral

\footnotetext{
${ }^{15}$ Ahmadi Miru dan Sakka Pati, Hukum Perikatan (Rajagrafindo Persada 2014).[69].
} 
agreement conducted by nadzir or heir of waqf property through inclusion of waqf deed, from the legal perspective guarantee of debt over waqf land violates permissible causes.

\section{Efforts on Case of Waqf Deed Inclusion as Debt's Collateral}

Land has important role in life, i.e. for living, religious activity, farming, trading, and etc. Therefore, it can be concluded that land is important commodity in people's life in Indonesia. In addition, with the rapid development of infrastructure construction done by the government, either central or regional government. As the land price increase annually and it rather impossible to acquire land for free; therefore, it could generate problems within society, especially related to the individual interest through abuse of authority given to them. One of it is abuse of authority conducted by nadzir as the manager of waqf property through inclusion of waqf property as debt's collateral to fulfil their individual need.

There are certain obstacles in dispute settlement on land waqf case, which majority caused by lack of understanding from nadzir towards official registration of land waqf towards the Waqf Deed Acting Officer or Pejabat Pembuat Akta Ikrar Wakaf (further abbreviated and mentioned as PPAIW) in form of waqf deed or Akta Ikrar Wakaf (further abbreviated and mentioned as AIW). PPAIW itself defined as officer who has authority given by minister to create AIW.

When the land included as waqf property hasn't been register on PPAIW, it could create uncertainty of legal status towards the waqf land. Even then, this could've been caused by nadzir (commonly individual) hasn't register themselves as the manager of the waqf land. Therefore, nadzir could conduct unlawfully without considering the laws on waqf.

Other obstacles that commonly met in society is the nadzir's bad management; even, it is common there is misunderstanding between nadzir, which cause prolonged conflict. This conflict caused by dispute of nadzir legality; when, the prior nadzir replaced with the new one without followed by nadzir replacement report that reported to the authorized officer on Local Office of Religious Affairs. 
Lack of understanding on law of waqf in Indonesian society is the task for the Indonesian Waqf Agency or Badan Wakaf Indonesia (further abbreviated and mentioned as BWI) as the supervising agency on the management of waqf property. Land waqf might be used not for the initial purpose stated in the waqf deed, which is easy for the transformation of waqf property status to be included as collateral, sold, and etc.

Dispute settlement that can be taken related to the waqf is through nonlitigation or alternative dispute settlement regulated on Article 62 Law Number 41 Year 2004, which stipulates:

1. Dispute settlement of waqf can be settled through musyawarah in order to achieve consensus;

2. If the dispute settlement intended in paragraph (1) failed, dispute can be settled through mediation, arbitration, or litigation.

Musyawarah in order to achieve consensus conducted to avoid any prolonged conflict. However, if the musyawarah failed to achieve consensus; then, it can be continued through mediation or sharia arbitration. Mediation more or less similar to the musyawarah, but mediation conducted with the assistance of mediator as intermediary agent, which has objective to give solution and best possible way of dispute settlement. Similar to mediation, sharia arbitration has arbiter functioned as intermediary agent and capable to gives suggestion and advice towards the disputing parties.

If musyawarah, mediation, and arbitration failed in settling the dispute on waqf; therefore, this dispute will be brought upon the religious court. Dispute settlement through the court regarded as the last resort; when, the non-litigation dispute settlement fails to achieve the consensus between the disputing parties.

State has certain role in regulating Law Number 41 Year 2004 on Waqf, especially related to the dispute settlement on waqf through non-litigation dispute settlement intended for answering demands on acceleration and society dynamics in managing more complex conflict. State provides opportunity to settle the dispute in accordance with the potential owned by the dispute settlement originating from the society itself. 
Existence of Law Number 41 Year 2004 on law perspective regarded as legal protection on waqf practice in Indonesia. Enactment of this law for all Indonesian people, its not limited on Muslims only. Waqf as religious institution has economical potential and benefit that need to be managed effectively and efficiently for the interest of worship matter, in order to realize public welfare and Indonesian people's welfare.

Through enactment of Law Number 41 Year 2004 on Waqf in addition with the enactment of Government Regulation Number 42 Year 2006 on Application of Law on Waqf; then, it will increase the government awareness to protect the land waqf that spread all over Indonesia. BWI itself formed with Law Number 41 Year 2004 as the supervisor on waqf property management that being misused by the irresponsible party.

In the case of inclusion of waqf deed as collateral, person who misuse the waqf property not in accordance with its waqf deed could be asked for responsibility either civil or criminal way. When, the person who misuse the waqf property is nadzir, which initially appointed to managed the waqf property itself for the sake of people welfare; therefore, BWI can intervene to uphold the regulation that have been clearly written in law on waqf. BWI allowed to unilaterally dismiss nadzir and suggest the replacement for the new one, either individual, association, or legal entity nadzir.

However, it does not reduce creditors' responsibility who have provided loans to debtors. Creditor still has its right to ask for responsibility in repayment of loan in accordance with the amount of debt loaned. Creditor will unable to execute the collateral as it is still in form of waqf land; therefore, debtor must settle its debt with all properties owned by creditor, either tangible or intangible assets; either already exist or will exist in the future. All property owned by debtor will become material collateral over the debt that have been given by creditor to them.

Land rights that included as waqf land can't be use as debt's collateral. Utilization of waqf property as debt's collateral contradicts Law Number 4 Year 1996 on Hak Tanggungan, which supported with Article 40 Law Number 41 Year 2004 on Waqf stipulates that waqf property is forbidden to be included as collateral (either by nadzir or wakif's heir), confiscated without any legally binding reasons, 
granted to other person besides the initial recipients of waqf benefits, sold, inherited to wakif's heir or nadzir's heir, traded or transferred into other right without any proper notice and consent from BWI as supervisor, which it decision known by Religious Affair Minister of Indonesian Republic.

Burgerlijk Wetboek has regulate under Article 1320, which explain that legal terms of agreement is through fulfilment of four characteristics, those are: capability, consent, certain matter, and allowed causes. Therefore, inclusion of waqf land as debt's collateral is not in accordance with Article 1320 BW, and Article 40 Law Number 41 Year 2004 on Waqf. Based on law, this collateral agreement didn't fulfil the fourth term of Article $1320 \mathrm{BW}$, which is allowed clause; therefore, it will cause the collateral agreement became null and void.

Even, in Law Number 41 Year 2004 contains article that stipulate criminal punishment for the person who misuse waqf property, which stipulated on Article 67 paragraph (1):

"Every person who intentionally include into collateral, grant, sell, inherit, transfer into other form of right waqf property as stated on Article 40 or without permission to exchange waqf property as stated in Article 41, may be punished with jail imprisonment for maximum 5 years sentences and/ or sentenced with fine maximum Rp.500.000.000,00 (five hundred million Rupiahs)”.

\section{Conclusion}

As stated on Article 40 Law Number 41 Year 2004 on Waqf, waqf land prohibited to be included as collateral, confiscated, bequested, sold, inherited, traded or any other forms of transfer of right. However, transformation of waqf land status could be excepted, if waqf land will be used for public interest correspond to General Spatial Plan or Rencana Umum Tata Ruang (RUTR) based on applicable laws that don't contradict Sharia.

In principle, the object of hak tanggungan are rights that fulfil two terms, those are: the right is in accordance with enacted regulation must be registered in general registration in Land affair office and based on its characteristic must be transferable. Therefore, ownership right that already included as waqf property can't be imposed 
with hak tanggungan, because in accordance to the principle of waqf, ownership right of the waqf property have been perpetuated into religious property. Loan agreement's is still valid, although the collateral agreement that declared null and void. debtor must settle its debt with all properties owned by creditor, either tangible or intangible assets; either already exist or will exist in the future. All property owned by debtor will become material collateral over the debt that have been given by creditor to them, which is in accordance with Article 1131 BW.

Dispute settlement that can be taken related to the waqf is through nonlitigation or alternative dispute settlement regulated on Law Number 41 Year 2004. However, if musyawarah, mediation, and arbitration failed in settling the dispute on waqf; therefore, this dispute will be brought upon the religious court. In accordance to Article 62, dispute settlement through the court regarded as the last resort; when, the non-litigation dispute settlement fails to achieve the consensus between the disputing parties.

Ministry of Religious Affair through Indonesian Waqf Agency or Badan Wakaf Indonesia regulated on Law Number 41 Year 2004 on waqf can impose their authority on giving coaching, managing and developing waqf property to maximize their task by giving coaching on nadzir as the manager of waqf property, socializing the existence of Law Number 41 Year 2004 on waqf towards public to make them realize the importance of sertification, management and development of waqf property properly in accordance with the enacted law. Therefore, nadzir or even wakif heir can maintain the trusteeship from wakif to manage the waqf property as the property which capable in giving benefit for all people and doesn't contradict the sharia' law.

\section{Bibliography}

Books

Adrian Sutedi, Hukum Hak Tanggungan (Sinar Grafika 2012).

Ahmadi Miru dan Sakka Pati, Hukum Perikatan (Rajagrafindo Persada 2014). 
Bahsan, Hukum Jaminan Dan Jaminan Kredit (Raja Grafindo Persada 2010).

Farid Wajdi dan Suhrawardi K, Hukum Wakaf Tunai (Citra Aditya Bakti 2016).

Rachmadi Usman, Hukum Jaminan Keperdataan (Sinar Grafika 2009).

Rachmadi Usman, Hukum Perwakafan Di Indonesia (Sinar Grafika 2013).

Soerjono Soekanto, Hukum Adat Indonesia (Rajagrafindo Persada 2012).

Suhrawardi K, Wakaf Dan Pemberdayaan Umat (Sinar Grafika 2010).

\section{Journal}

Fatma Paparang, 'Implementasi Jaminan Fidusia Dalam Pemberian Kredit Di Indonesia' (2014) 1 LPPM Bidang EkoSosBudKum.

\section{Thesis}

Husein Syahatah, Perlindungan Aset Publik Dalam Perspektif Hukum Islam (Bumi Aksara 2005).

Novita Try Jayanti, 'Penggunaan Tanah Wakaf Untuk Pembangunan Rumah Susun' (Universitas Airlangga 2018).

\section{Regulations}

Law Number 01 of 1974 concerning Marriage (Indonesia State Gazzete Year 1974 Number 1, Additional of Indonesian State gazzete Number 3019).

Law Number 42 of 1999 concerning Fiduciary Guarantee (Indonesia State Gazzete Year 1999 Number 168, Additional of Indonesian State gazzete Number 3889).

Law Number 41 of 2004 concerning Waqf (Indonesia State Gazzete Year 2004 Number 159, Additional of Indonesian State gazzete Number 4459).

Law Number 20 of 2011 concerning Strata Title (Indonesia State Gazzete Year 2011 Number 108, Additional of Indonesian State gazzete Number 5252).

HOW TO CITE: Intan Avi Savila, Made Ayu Trisnawati and Notaricia Sartika, 'Status of Waqf Properties As Debt's Collateral' (2019) Vol. 2 No. 1 Notaire. 
--halaman ini sengaja dibiarkan kosong-- 